\title{
Sex and Sensation in the Nineteenth-Century Novel
}

\author{
SIOBHÁN KILFEATHER
}

To dream of a hearse with white plumes is a wedding; but to dream of a wedding is grief, and death will follow.

To dream of a woman kissing you is deceit; but of a man, friendship; and to dream of a horse is exceedingly lucky. ${ }^{1}$

The fact is, though it is difficult for an outsider to believe it, that the whole subject of love, of passion of any kind, especially from a girl and with regard to her own marriage, is such an utterly unheard-of one amongst Grania's class that the mere fact of giving utterance to a complaint on the subject gave her a sense not merely of having committed a hideous breach of common decency, but of having actually crossed the line that separates sanity from madness. ${ }^{2}$

Emily Lawless, in Grania (1892), tackles a problem that haunts much nineteenthcentury Irish fiction: how to represent the (presumably) inarticulate masses, without merely re-presenting stereotypes associated with stage-Irishry and the brogue. Lawless gestures towards a recognition of this problem in her dedication: 'the possibility of an Irish story without any Irish brogue in it - that brogue which is a tiresome necessity always'. In her heroine, Grania O'Malley, named for an almost mythical figure from Irish history, Lawless creates a subjectivity whose complexities are indicated by sense, feeling and intuition rather than articulation, a woman isolated from her community by a superior sensibility which she has no words to explain, even to herself. The grandeur of Grania's nature is mapped directly onto the bleak grandeur of the landscape - the novel's subtitle is 'the story of an island', and the frontispiece is a map of the Aran Islands. None of Lawless's characters is liberated - except in death - from the confines of what the novelist presents as a narrow and rigid world-view. Grania never succeeds in articulating her discontents to her lover or to herself. The drama of their conflict requires a richness of language in the interplay between free indirect discourse and omniscient narrative to suggest to the reader the meaning of Grania's social, sexual and spiritual frustrations.

I Jane (Lady) Wilde, Ancient Legends, Mystic Charms, and Superstitions of Ireland. With Sketches of the Past (1888; republished Galway, 1971), p. 208. of an Island, (London, I892), p. 249.

2 Envily Lawless, Grania: The Story 
Terry Eagleton writes that in nineteenth-century Ireland 'the sexual culture of the nation belonged to a complex economy of land and inheritance, property and procreation. As far as sexuality goes, we are speaking less of the erotic or psychological than of dowries and matchmakers'. ${ }^{3}$ At one level, Lawless's novel would seem to concur with the view that Irish sexuality is so materially located as to exclude expressions of desire and sensuality, to make such expressions seem absurd or insane. At another level, the very posing of the problem of how to articulate desire within the novel suggests that the sociological or anthropological model for recording Irish sexualities is inadequate to the lived experience of those sexualities. Eagleton argues that it is with the modernism of Moore, Wilde and Joyce that 'sexuality becomes a metaphor for political revolt'. Eagleton's description of the sociological model is true to one dominant discursive mode of constructing Irish sexualities, the sketches of Irish life that run through those texts of political economy, travel writing, fiction, memoirs, journalism and apologies that seem to look to a British as well as Irish audience. Many of these incorporate an homage to the possibility of self-representation of the masses, in so far as they include documentation such as interviews or testimonies presented in court, to journalists, or to officials such as census takers or Poor Law Commissioners. In general these texts offer a contrast between the obfuscation of Irish speech - its deviousness, its foreignness, its intrinsic absurdities - and the apparent transparency of hunger and poverty as written on the body of the peasant. I began this essay with a quotation from Jane Wilde to indicate that there was some recognition in nineteenth-century literature that popular superstitions, folklore and ballads might be some of the languages in which ordinary people articulated the complexities of desire, and that the inverted logic of dreams has a pronounced role in such articulations. I want to argue that the novel is a significant source of information about sexuality because of its special ability to incorporate conflicting discourses, without necessarily reconciling them, and that in nineteenth-century Irish fiction there are recurring dramatisations of a great silence around sex.

Terry Eagleton, a propos his argument that the major nineteenth-century Irish novelists are 'engaged in a kind of performative contradiction', producing texts 'colonial in their very letter', cites William Carleton as an example.

[T] he speech of Carleton's characters can also veer from one linguistic form to the other within one sentence ... Young Dalton, one of the labouring poor of The Black Prophet ( 1847 ), manages to produce this earthy, monosyllabic praise of the woman he loves: 'Upon my honour, Donnel, that girl surpasses anything I have seen yet. Why, she's perfection - her figure is - is - I havn't [sic] words for it - and her face - good heavens! what brilliancy and animation!'Young Dalton's problem is that he has all too many words for it ...4

3 Terry Eagleton, Heathcliff and the Great Hunger: Studies in Irish Culture (London, I995), p. 227. 4 Ibid., p. 209; William Carleton, The Black Prophet:A Tale of Irish Fantine (Belfast, I847), p. I I 8. Eagleton slightly mis-remembers here: the speaker is young Dick but the elaborate performance of speechlessness is the relevant point. 
Eagleton makes this point in a context where he argues that what the Irish novelists have no words for is a history so 'crisis-racked, excessive, hyperbolic, unlikely, where 'life itself is sometimes a great deal more improbable than the most sensationalist of tales'. I make no apology for returning to the question of realism in the nineteenth-century novel, since criticism has so readily agreed that this is the issue. ${ }^{S}$ Although the narrative of nineteenth-century fiction is often traced from Edgeworth to Somerville and Ross, I would argue that in this debate there is an exclusion of a certain kind of women's writing and a demotion of the melodramatic and sensationalist aspects of nineteenth-century fiction that in Britain were associated with an appeal to women readers. ${ }^{6}$ It is when he tries to describe the body of Sally M'Gowan that words fail young Dick. Nineteenth-century Irish novels have as much trouble representing bodies and sexuality as in representing famine, dispossession and emigration. This is not because sex is simply an unspeakable subject in nineteenth-century Ireland, but because Irish writers reject the domestication of sexuality in ways that disrupt and depose the conventions of realist fiction.

The use of the word 'sensation' to describe excited or violent feelings dates from the late eighteenth century and by the beginning of the nineteenth century 'sensational', like the recently coined term 'melodramatic', was being associated strongly both with popular theatre and with newspaper reporting of crime. In literary criticism 'sensation fiction' is a term very specifically applied to a group of novels published in England in the 1860 s, many published by Bentley and by Maxwell, some serialised in periodicals edited by women: the best-known of the sensation novelists are Wilkie Collins, Mary E. Braddon, Mrs Henry Wood, Sheridan Le Fanu, Charlotte Riddell and Rhoda Broughton. Jenny Bourne Taylor suggests that Wilkie Collins transposes 'the disruptive and disturbing elements of Gothic fiction into the homely setting of the family and the everyday, recognisable world, thus generating suspense and exploiting undercurrents of anxiety that lie behind the doors of the solid, recognisable, middle-class home. ${ }^{7}$ While many critics have followed W.J. McCormack's analysis of Le Fanu into recognition of

5 See Thomas Flanagan, The Irish Novelists, 1800-1850 (New York, 1959); John Cronin, The Anglo-Irish Novel, Volume One: The Nineteenth Century (Belfast, 1980); Seamus Deane, A Short History of Irish Literature (London, 1986); Barry Sloan, The Pioneers of Anglo-Irish Fiction: 1800-1850 (Gerrard's Cross, 1986); Seamus Deane (ed.) The Field Day Anthology of Irish Writing (3 vols; Derry, 199I). 6 'The sensationalists made crime and violence domestic, modern, and suburban; but their secrets were not simply solutions to mysteries and crimes; they were the secrets of women's dislike of their roles as daughters, wives, and mothers. These women made a powerful appeal to the female audience by subverting the traditions of feminine fiction to suit their own imaginative impulses, by expressing a wide range of suppressed female emotion, and by tapping and satisfying fantasies of protest and escape'; see Elaine Showalter, A Literature of Their Own: British Women Novelists from Brontë to Lessing (1977; revised edition, London, 1984), pp. 158-9. 7 Jenny Bourne Taylor, In the secret theatre of home: Wilkie Collins, sensation narrative and nineteenth-century psychology (London, I988), p. I. 
the symbolic and allegorical valences of the so-called Protestant Gothic, with its narratives of aristocratic decay, there has been a concomitant denigration of, or apology for, 'Catholic' bourgeois fiction (McCormack is an exception). ${ }^{8}$ Eagleton, for example, recognises Protestant Gothic as 'the political unconscious of Irish society'; ' but in discussing The Black Prophet he identifies a striking 'hiatus' between 'story and society': 'Carleton can find no way of anchoring his narrative in the social conditions he depicts; instead the latter threaten at times to become a mere context for the former, which irrelevantly revolves on a twenty-year old murder.' ${ }^{\text {Io }}$ Other critics have depicted the Irish novel as undermined by these dislocations. According to Thomas Flanagan,

The history of the Irish novel is one of continuous attempts to represent the Irish experience within conventions that were not congenial to it ... The best of them, which seek to move beyond these forms, make their strongest points and exist most vividly through indirection, symbol, allusion, and subtle shifts of points of view. ${ }^{11}$

John Cronin precedes Terry Eagleton in finding the plot of The Black Prophet inadequate to its anthropological and political concerns:

Ideally the terrible realities of the truths in his novel cried out for a sturdy plotstructure to match them and symbols grand enough to do justice to his fearsome theme. Sadly, what he offers instead is an unconvincing story of rural murder and mystery which is intended to generate, in relation to the contemporary events of the novel, an atmosphere of tension and horror. ${ }^{12}$

It might be profitable to move from the presumption that these are failed realist texts to think of their sensational and melodramatic elements as the vehicles for certain kinds of critique. It is not simply that Irish life had its sensational and melodramatic aspects, for which novelists such as Carleton strove to achieve what Margaret Oliphant ascribed to the sensation novelists - 'a kindred depth of effect and shock of incident'. ${ }^{13}$ The Black Prophet is, of course, exemplary of a narrative and imaginative problem foregrounded in the debate between Edmund Burke and Thomas Paine on the French Revolution, the problem of representing the suffering of the masses as dramatically or affectively as the story of an individual, particularly of a literate, self-reflective individual. Sensational fiction offered writers the opportunity to interrogate the mechanisms by which grand historical narratives invade and evacuate individual subjectivities in what are conventionally presented as the private spaces of home, family and sexuality.

8 See W.J. McCormack, Sheridan Le Fanu and Victorian Ireland (Oxford, 1980) and McCormack's introduction to 'Language, Class and Genre' in The Field Day Anthology of Irish Writing i, pp. 1070-82. 9 Eagleton, Heathcliff and the Great Hunger, p. 187. Io Ibid., p. 212. II Flanagan, The Irish Novelists, p. 334. I2 Cronin, The Anglo-Irish Novel, p. 92. 13 Margaret Oliphant, article in Blackwood's Edinburgh Magazine 1862, quoted by Taylor, In the secret theatre of home, p. 3 . 
I am aware of the dangers of adapting the very specific use of 'sensation fiction' to include a much larger group of generically mixed texts over a much longer period in Ireland. I have argued elsewhere that there existed amongst eighteenthcentury Irish and Scottish writers a sufficient alienation from English literature to foster the development of gothic fiction as a critique of 'progress' from the margins. ${ }^{14} \mathrm{I}$ want to argue here that in the nineteenth century Irish writers responded to the demands of new discursive formations about Irish reality, and to the tensions of negotiating between the slightly different demands made upon them, by a variety of British readerships and Irish readerships, to discover the uses of sensationalism. As a specifically literary, historical argument I would identify Gerald Griffin's The Collegians (I829) as the foundational fictional text in this transformation. It would be mistaken, on several counts, to insist too schematically either on a rigid distinction between English and Irish novelists - after all, Charlotte Riddell and Sheridan Le Fanu can be incorporated into the narrative of English sensation fiction - or between sensational and realist texts. One might question the usefulness of categorising Clarissa or Emma as realist novels, in so far as such categorisation necessarily belies interesting elements of those texts. More importantly, perhaps, Jenny Bourne Taylor warns of the dangers of privileging sensational novels as the site of madness and 'otherness', 'making them the bearers of a more authentic truth'. ${ }^{\text {Is }}$ It is possible to look at the sensational aspects of writers such as Griffin, Carleton, Le Fanu, Frances Browne, Sarah Grand and George Moore without denying that they have other striking generic affiliations, not all of which are necessarily best read in an Irish context.

Jenny Bourne Taylor describes the middle-class English home of sensation fiction as a 'secret theatre', operating behind closed doors. Irish novels place much more emphasis on open doors, from cabin to big house, but the house open to hospitality and community is also open to surveillance. In the most famous depiction of the middle-class home in nineteenth-century fiction - breakfast at the Dalys' in The Collegians - the room is an over-determined text, the apparently transparent domesticity riven with incongruity and contradiction. One of the novel's motifs, in fact, is spatial contrast. In terms of landscape this involves a reiterated mystique of the west, where landscapes are more dramatic and life lived at a greater pitch of intensity. ${ }^{16}$ The nobility of Myles and the unruliness of Poll both have their true homes in the west, and it is appropriate that at the novel's conclusion Hardress is seeking his death on a westward voyage, just as Mihil is being carried to a grave in the west.

The allegorisation of space is just as striking in the representation of interiors, particularly in the repeated use of adjacent rooms to house irreconcilable narratives. The chasm between the classes is represented, for example, when

14 Siobhán Kilfeather, 'Origins of the Irish Female Gothic' in Bullán, i, 2 (Autumn I994), pp. 35-45. I5 Taylor, In the secret theatre of home, p. 17. I6 For a discussion of the western landscape, and particularly Killarney, in Victorian melodrama, see Luke Gibbons, 'Landscape and character in Irish romantic melodrama' in Kevin Rockett, Luke Gibbons and John Hill, Cinema and Ireland (London, 1987), pp. $210-21$. 
Hardress cripples Danny Mann by pushing him downstairs; while Hardress's muted alienation from his own class is most strikingly presented when he stands at the deathbed of Dalton, the huntsman, who is being teased by drunken revellers in the adjoining room. The organisation of domestic space is also a mode for conveying several undercurrents of passion that cannot erupt into social space. In the chapters at the Dairy Cottage, for example, while Kyrle is advocating the necessity of certain social hypocrisies, he is opening his heart to Hardress, while Hardress, the advocate of frankness, refuses to acknowledge the anguish of Eily, pacing the floors of another room. At Poll Naughten's cottage, Eily is repeatedly represented as moving in and out of her own room, and this movement provides Danny Mann's testimony with one opportunity for evasion:

Questioned, If he were not present in said Naughten's house, when said Eily (deceased) said Looby being then in Naughten's kitchen, did give a letter to Poll Naughten, sister to prisoner, addressed to Dunant O'Leary, hair-cutter, Garryowen, and containing matter in the handwriting of said Eily; answereth, How should he (prisoner) see through stone walls. ${ }^{17}$

The anti-naturalistic presentation of space also opens up possibilities for representations of the fantastic. At her first appearance Anne Chute is passing around a drawing of Castle Chute the house in which the party is gathered and yet Hyland Creagh does not recognise the scene. Castle Chute is the place of two 'supernatural' visions; Dan Dawley's comic encounter with the Chute family ghosts at the start of the novel is echoed by a moment towards the end when Danny Mann's guards mistake Hardress for a ghost.

Luke Gibbons, in an essay on Killarney and the politics of the sublime, argues that the recurrence of supernatural motifs in eighteenth-century Irish literature provides one of the few means by which the legitimacy of the colonial settlement can be contested, and quotes Tzvetan Todorov: 'The function of the supernatural is to exempt the text from the action of the law, and thereby to transgress that law'. ${ }^{18}$

Griffin presents the Irish peasantry as a people 'at war with the laws by which they are governed ... There is scarcely a cottage in the south of Ireland, where the very circumstance of legal denunciation would not afford, even to a murderer, a certain passport to concealment and protection'. ${ }^{19}$ There is a more textually interesting association with the law in Griffin. What chiefly justifies describing The Collegians as sensational is the novel's relationship to crime reporting. Showalter and Taylor point out that sensation fiction in England is concurrent with a huge public interest in murder trials, particularly trials of young women

17 Gerald Griffin, The Collegians: A Tale of Garryowen (1829; London, [1842]), p. 242. 18 Luke Gibbons, 'Topographies of Terror: Killarney and the Politics of the Sublime' in SAQ, 95, I (Winter 1996), pp. 23-44, p. 38; Tzvetan Todorov, The Fantastic: A Structural Approach to a Literary Genre (Ithaca, 1975), p. 33.

19 Griffin, The Collegians, p. 243. 
such as Madeleine Smith and Constance Kent. Jonah Barrington's recollections are one testimony to Irish public interest in crime. It has been observed that Griffin's historical setting for The Collegians is complicated by public memory of the much more recent murder of Ellen Hanlon. Later editions of the novel reiterate that memory by printing Curran's narrative of the murder from the New Monthly Magazine as an appendix. The juxtaposition of novel and narrative has the effect of demonstrating how inadequate explanation and motivation are to the crime. The discrepancies within and between the two texts draw attention to the ways in which various discourses - law, reportage, imaginative fiction stand in for and gesture towards sexual passion and domestic violence but can never sufficiently account for that excess. The seduction of Eily, as much as her murder, happens off-stage.

It has been persuasively argued that newspaper reporting of sex crimes tends to produce conservative and normative versions of appropriate female behaviour, blaming the victim. ${ }^{20}$ It is tempting but unproductive to suggest that what has been silenced in The Collegians is Eily's voice. Eily's voice is, in fact, foregrounded in a bizarre call to realism within the text, namely the dream of Hardress Cregan, where he introduces Eily to his rich and fashionable acquaintances, and is shamed by 'the bashfulness, the awkwardness, and the homeliness of speech and accent, with which the ropemaker's daughter received their compliments' and at the sight of her peeling a potato with her fingers. 'He dreamed, moreover, that when he reasoned with her on this subject, she answered him with a degree of pert vulgarity and impatience which was in "discordant harmony" with her shyness before strangers'. ${ }^{21}$ The dream, like the scene at the Dairy Cottage, suggests that Hardress is not at all free from social concerns, as he pretends, but it is tonally a very different kind of revelation from that found in dreams in other novels, where the dreamer is overwhelmed by memory or unacknowledged, even unfocused, desires. In The Black Prophet, Donnel Dhu dreams that Condy Dalton is hammering a nail into his coffin. Sarah Grand's The Heavenly Twins and George Moore's Evelyn Innes are just two examples of novels featuring young women who live 'in a state of exquisite feeling', sexually aroused by powerful dreams. ${ }^{22}$ Dreams perform many different functions in texts; in these novels they permit an indulgence of sensuousness without reflection or judgement. In The Heavenly Twins, of course, the end consequence of Edith's dream is her syphilitic baby and her own descent into insanity.

20 For accounts of this phenomenon in different periods see Anna Clark, Women's silence, men's violence: sexual assault in England 1770-1845 (London, 1987); Keith Soothill and Sylvia Walby, Sex Crime in the News (London, I99I); Judith Walkowitz, City of Dreadful Delight (London, 1992); James Kelly, "A Most Inhuman and Barbarous Piece of Villainy": An Exploration of the Crime of Rape in Eighteenth-Century Ireland' in Eighteenth-Century Ireland/ Iris an dá chultúr, 10 (1995), pp. 78-107. 21 Griffin, The Collegians, p. 126. 22 Sarah Grand, The Heavenly Tivins (London, I 893; reprinted Ann Arbor, 1992), pp. I 57 ; 'The face rose up to hers. She looked into the subtle eyes, and the thrill of the lips, just touching hers, awakened a sense of sin; and her eyes when they opened were frightened and weary', George Moore, Evelyn Innes (London, I898) p. 33. 
Elizabeth Bowen, in an introduction to a reprint of Sheridan Le Fanu's Uncle Silas, suggests that

Uncle Silas is, as a novel, Irish in two other ways: it is sexless and it shows a sublimated infantilism. It may, for all I know, bristle with symbolism; but I speak of the story, not of its implications - in the story, no force from any one of the main characters runs into the channel of sexual feeling. ${ }^{23}$

Bowen, in her own fiction a mistress of indirection, knows quite well, of course, how the novel bristles with sexuality, but in distinguishing between the story and implications she executes a divorce which everything in the text militates against. Maud's dream of her father's face 'sometimes white and sharp as ivory, sometimes all hanging in cadaverous folds, always with the same unnatural expression of diabolical fury' connects the sexuality and infantilism. ${ }^{24}$ Only in her dreams can Maud accuse her father of terrorising her, and only in fiction is there an acknowledgement that illicit intergenerational passions can fracture the home.

I began by suggesting that novelists have as much problem representing bodies and sexuality as famine and dispossession. One reason for this may be that the two had become intimately associated in discursive constructions of nineteenthcentury Ireland. Feminists in Britain, many of whom offered powerful critiques of the family as a British institution, identified it as a site of resistance in Ireland. ${ }^{25}$ In particular, they drew on the work of the Poor Law Commission to suggest that Irish chastity and domesticity were undermined by poverty and misgovernment. 'The admirable tales of Banim and Carleton have, I trust, paved the way for the success of the TRUE STORIES of the Irish Peasantry told to the Poor-Law Commissioners,' announces Christian Johnstone. Johnstone and successive apologists for the Irish peasantry contributed to the production of a moral climate in which unruly, illegitimate sexuality became unrepresentable. Frances Power Cobbe offers a powerful image of this unspeakability: 'There is a peculiarly ferocious scream, really worthy of wild beasts, practised among these wretched girls whenever a mutiny takes place. It is called the poorhouse scream' ${ }^{26}$ In

23 Sheridan Le Fanu, Uncle Silas: A Tale of Bartram-Haugh (1864; reprinted with an introduction by Elizabeth Bowen, London, 1947). Introduction reprinted in Collected Impressions (London, 1950) and in The Mulberry Tree, edited by Hermione Lee (London, 1986) pp. I00-13; 10I-2. 24 Le Fanu, Uncle Silas, ch. 29. 25 Christian Johnstone, True Tales of the Irish Peasantry, As Related by Themselves, Selected from the Report of the Poor Law Commissioners (Edinburgh, 2nd edition, 1836), preface; Frances Power Cobbe, Essays on the Pursuits of Women Reprinted from Fraser's and Macmillan's Magazines (London, 1862); Annie Besant, Coercion in Ireland and Its Results (London, I882); Josephine E. Butler, Our Christianity Tested by the Irish Question (London, 1887). 26 Cobbe, Essays on the Pursuits of Women, p. 192. I must emphasise that I am interested here primarily in modes of representation. For a discussion of women's historical experience, see Maria Luddy and Cliona Murphy (eds), Women Surviving: Studies in Irish Women's History in the Nineteenth and Twentieth Centuries (Dublin, 1989), particularly chapters by Luddy on prostitution and by Dympna McLoughlin on workhouses. 
contrast to this scream novelists increasingly present a chasm of silence on the subject of sexuality.

The turn to melodrama or sensation allows the juxtaposition, as opposed to reconciliation, of violently disparate material. If the black prophet's murder is insufficiently motivated or explained then so is the behaviour of Sally's 'unnatural' mother, and so is the famine, but these things are not made to stand for one another. Sensational plots also require an interrogation of the borders of sanity and insanity, sometimes the terrain of dreams. At the height of sensation fiction's popularity, which was also the period when feminists were campaigning for repeal of the Contagious Diseases Acts, Frances Browne's novel, The Hidden Sin (which starts, like The Black Prophet, with an old Irish murder for money) situates insanity precisely as a colonial legacy:

'Yermiska was a Tartar Moslema, accustomed to think of revenge, but never of revolt or disobedience; and the night before her marriage she deliberately drank a potion ... How, or of what that draught was compounded, the Powers of Darkness best know; but the Princess declared, and time has proved her statement true, that it would transmit hereditary and irremediable madness to the utmost generation of her descendants.

'You look incredulous, my friend. There are secrets in nature for which the boasted science of Europe has neither name nor place... That knowledge, like all the deeper and higher sorts, has no written records. It cannot be found in books; they contain but the husks and rinds of learning, being meant for the common eye and mind. It exists, nevertheless, among primitive and unlettered races; the African slave and the Hindoo pariah have visited the sins of the fathers upon the Anglo-Saxon families by means similar to those which the unwilling bride employed against mine. ${ }^{27}$

D.A. Miller, in his study of Wilkie Collins and otherVictorian English novelists, suggests that the point of the nineteenth-century novel 'is to confirm the novelreader in his identity as "liberal subject", a term with which I allude not just to the subject ... but also to, broadly speaking, the political regime that sets store by this subject'. ${ }^{28}$ In his chapter on Collins, Miller suggests that what is sensational about the sensation novel is the somatic experience of sensation in reading it, and that these sensations the ones felt on the pulses of the reader's body, help to disavow the text's apparent interpretations of its own sensationalism. 'Reader, if you have shuddered at the excesses into which he plunged, examine your own heart ...' begins the final paragraph of The Collegians, confident that the reader has been physically, sensibly and sensationally, as well as morally and mentally moved by the events. ${ }^{29}$ One might argue that in asking the reader to identify, however provisionally, with Eily's seducer and murderer Griffin acknowledges a 
failure to identify with Eily and her class. On the other hand, a recognition of the power of sexual passions casts a melancholy and sinister hue on the rational domesticity of the Dalys, whose expression is as much the childbed death as the family breakfast feast.

At the close of the century Horace Plunkett was to express his concern that excessive sexual surveillance was driving people to emigration: 'In some parishes the Sunday cyclist will observe that strange phenomenon of a normally lighthearted peasantry marshalled in male and female groups along the road, eyeing one another in dull wonderment across the forbidden space'. ${ }^{30}$ If some novels sought to represent this bleakness, other chose to intervene and breach the space by concentrating on fantasy rather than realities.

30 Horace Plunkett, Ireland in the New Century (London, 1904; revised edition, London, I905), р. I 16. 